\title{
Ligand Effects on Structural, Protophilic and Reductive Features of Stannylated Dinuclear Iron Dithiolato Complexes
}

Hassan Abul-Futouh, ${ }^{\text {a }}$ Laith R. Almazahreh, ${ }^{\text {b,c }}$ Sara J. Abaalkhail, ${ }^{a}$ Helmar Görls, ${ }^{\text {c }}$ Sven. T. Stripp $^{\mathrm{d}}$ and Wolfgang Weigand ${ }^{* c}$

${ }^{a}$ Department of Pharmacy, Al-Zaytoonah University of Jordan, P.O. Box 130, Amman 11733, Jordan. Email: h.abulfutouh@zuj.edu.jo.

${ }^{b}$ ERCOSPLAN Ingenieurbüro Anlagentechnik GmbH, Arnstädter Straße 28, 99096 Erfurt, Germany.

${ }^{c}$ Institut für Anorganische und Analytische Chemie, Friedrich-Schiller-Universität Jena, Humboldt Str. 8, 07743 Jena, Germany.E-mail: wolfgang.weigand@uni-jena.de.

${ }^{d}$ Bioinorganic Spectroscopy, Department of Physics, Freie Universität Berlin, Arnimallee 14, 1495 Berlin, Germany

Keywords: Hydrogenase, Iron, Tin, Substitution, Protonation, Cyclic Voltammetry, Hydride.

\begin{abstract}
The synthesis and characterization of $\mathrm{Fe}_{2}(\mathrm{CO})_{5}(\mathrm{~L})\left\{\mu-\left(\mathrm{SCH}_{2}\right)_{2}\right\} \mathrm{SnMe}_{2}\left(\mathrm{~L}=\mathrm{PPh}_{3}(\mathbf{2})\right.$ and $\mathrm{P}(\mathrm{OMe})_{3}$ (3) derived from the parent hexacarbonyl complex $\mathrm{Fe}_{2}(\mathrm{CO})_{6}\left\{\mu\right.$-( $\left.\left(\mathrm{SCH}_{2}\right)_{2}\right\} \mathrm{SnMe}_{2}(\mathbf{1})$ is reported. Whereas 1 exhibits a unique planar structure, X-ray crystallography showed that the apical orientation of $\mathrm{L}$ in complexes 2 and 3 results in a chair/boat conformation of the $\mathrm{Fe}_{2} \mathrm{~S}_{2} \mathrm{C}_{2} \mathrm{Sn}$ fused six-membered rings, which is typical for diiron dithiolato complexes. In solution, NMR and FTIR spectroscopic techniques provide evidence for a dynamic process of apical-basal site exchange of the ligand $\mathrm{L}$ in $\mathbf{2}$ and $\mathbf{3}$. Protonation experiments on $\mathbf{2}$ and $\mathbf{3}$ in $\mathrm{MeCN}$ using $\mathrm{CF}_{3} \mathrm{CO}_{2} \mathrm{H}, \mathrm{HCl}$ or $\mathrm{HBF}_{4} \cdot \mathrm{Et}_{2} \mathrm{O}$ suggest enhanced protophilicity of the $\mathrm{Fe}-\mathrm{Fe}$ bond due to the presence of the electron donor ligands $\mathrm{L}$ as well as the stannylation effect. While the carbonyl ligands in $\mathbf{2}$ stretch at lower wavenumbers $v(\mathrm{CO})$ than those in $\mathbf{3}$, the cyclic voltammetric reduction of $\mathbf{2}$ unpredictably occurs at less negative potential than that of $\mathbf{3}$. In contrast to $\mathbf{1}$, the presence of $\mathrm{PPh}_{3}$ and $\mathrm{P}(\mathrm{OMe})_{3}$ in 2 and 3, respectively, allows protonation prior to reduction as shown by FTIR spectroscopy and cyclic voltammetry.
\end{abstract}




\section{Introduction}

During the past two decades, considerable attention has been paid to search for viable alternatives for clean and renewable energy sources. Therefore, hydrogen has been gaining importance due to its affordability and environmental friendliness. ${ }^{1-4}$ The high ability of [FeFe]-hydrogenases in catalyzing the production of hydrogen through reduction of protons makes their active site an interesting target for biomimetic modeling. ${ }^{5-10}$ The active site of these enzymes, the so-called $\mathrm{H}-$ cluster (Figure 1A), features a binuclear iron sub-site that is coordinated by an azadithiolato bridging moiety as well as carbon monoxide and cyanide ligands. ${ }^{11-14}$ In addition, a canonical ironsulfur cluster $([4 \mathrm{Fe} 4 \mathrm{~S}])$ is linked to one iron atom through a cysteine ligand. ${ }^{11-13}$ The reaction mechanism of $\mathrm{H}_{2}$ oxidation and $\mathrm{H}^{+}$reduction at the $\mathrm{H}$-cluster is under discussion. ${ }^{14}$

(A)

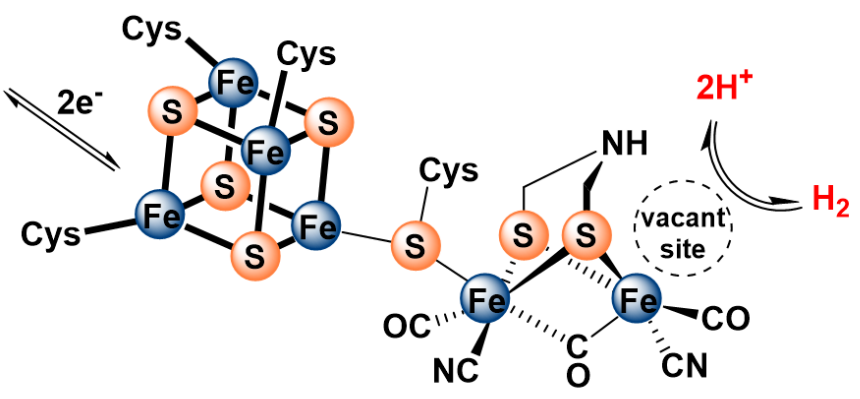

(B)

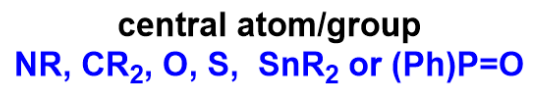

\section{phosphines and phosphites \\ alternative ligands \\ $\mathrm{PMe}_{3}, \mathrm{P}(\mathrm{OMe})_{3}, \mathrm{P}(\mathrm{OEt})_{3}$}

Figure 1. (A) Structure of the H-cluster. (B) Synthetic model of the active site of [FeFe]hydrogenase.

For several years, extensive efforts have been devoted to designing structural and functional models so as to mimic the protonation and redox properties of the H-cluster. ${ }^{15-24}$ These models include a variety of dithiolato ligands, $\mu-\left(\mathrm{SCH}_{2}\right)_{2} \mathrm{X}$, in which the central atom/group $\mathrm{X}$ could be $\mathrm{NR}, \mathrm{CR}_{2}, \mathrm{O}, \mathrm{S}, \mathrm{SnR}_{2}$ or $(\mathrm{Ph}) \mathrm{P}=\mathrm{O}$ (Figure $\left.1 \mathrm{~B}\right) .{ }^{25-39}$ Moreover, several research groups have reported approaches for introducing strong $\sigma$-donor ligands, such as phosphines and phosphites, at the diiron core to enhance the protophilicity of the model complexes (Figure 1B). ${ }^{40-57}$ In fact, 
multisubstituted complexes can be fully protonated affording bridging hydride $(\mu-\mathrm{H})$ products using strong or moderately strong acids. ${ }^{55,56}$ In comparison, monosubstituted complexes have been little investigated in terms of protonation features. To the best of our knowledge, only one recent article has been published, which describes the protonation features of monosubstituted complexes $\mathrm{Fe}_{2}(\mathrm{CO})_{5}\left(\mathrm{EPh}_{3}\right)\left\{\mu-\left(\mathrm{SCH}_{2}\right)_{2}\right\}(\mathrm{E}=\mathrm{P}, \mathrm{As}, \mathrm{Sb})$ containing only the $\mathrm{Fe}-\mathrm{Fe}$ bond as a plausible basic site. ${ }^{58}$ This study has shown that the addition of $c a .5$ equiv. $\mathrm{HBF}_{4} \cdot \mathrm{Et}_{2} \mathrm{O}$ to a solution of $\mathrm{Fe}_{2}(\mathrm{CO})_{5}\left(\mathrm{EPh}_{3}\right)\left\{\mu-\left(\mathrm{SCH}_{2}\right)_{2}\right\}(\mathrm{E}=\mathrm{P}, \mathrm{As}, \mathrm{Sb})$ in $\mathrm{CD}_{2} \mathrm{Cl}_{2}$ leads to the formation of small amount (ca. $5 \%)$ of bridging hydride $\left[\mathrm{Fe}_{2}(\mu-\mathrm{H})(\mathrm{CO})_{5} \mathrm{EPh}_{3}\left\{\mu-\left(\mathrm{SCH}_{2}\right)_{2}\right\}\right]\left[\mathrm{BF}_{4}\right](\mathrm{E}=\mathrm{P}, \mathrm{As}, \mathrm{Sb})$ complexes.

In our previous investigation, we have shown that the introduction of $\mathrm{Sn}$ atom into the dithiolato moiety of [FeFe]-hydrogenase model complexes, e.g. $\mathrm{Fe}_{2}(\mathrm{CO})_{6}\left\{\mu-\left(\mathrm{SCH}_{2}\right)_{2} \mathrm{SnMe}_{2}\right\}$ (1), increases the electron density of the $\mu-\mathrm{S}$ atoms and the Fe-Fe bond. ${ }^{38}$ Moreover, we have revealed that further enhancement of the protophilicity of the Fe-Fe bond is established by replacing the $\mu-\mathrm{S}$ in 1 by $\mu$-Se, and hence the use of moderately strong $\mathrm{CF}_{3} \mathrm{CO}_{2} \mathrm{H}$ was sufficient to protonate the $\mathrm{Fe}-\mathrm{Fe}$ bond. ${ }^{39}$ In the present study, we investigate the influence of substituting one $\mathrm{CO}$ in $\mathbf{1}$ by stronger electron donating ligands, $\mathrm{PPh}_{3}$ and $\mathrm{P}(\mathrm{OMe})_{3}$, toward the protonation properties of the resulting complexes, namely $\mathrm{Fe}_{2}(\mathrm{CO})_{5}(\mathrm{~L})\left\{\mu-\left(\mathrm{SCH}_{2}\right)_{2}\right\} \mathrm{SnMe}_{2}\left(\mathrm{~L}=\mathrm{PPh}_{3}(2)\right.$ and $\mathrm{P}(\mathrm{OMe})_{3}(3)$. Herein, the synthesis and characterization as well as the molecular structures of complexes $\mathbf{2}$ and $\mathbf{3}$ are described. Furthermore, the protonation properties of the complexes have been investigated by means of IR, ${ }^{1} \mathrm{H}$ and ${ }^{31} \mathrm{P}\left\{{ }^{1} \mathrm{H}\right\}$ NMR spectroscopic techniques. The cyclic voltammetry of these complexes is employed to gain insights into reduction features in the absence and presence of acid.

\section{Results and discussion}

\section{Synthesis and characterization}

A solution of complex 1 in $\mathrm{MeCN}$ was treated with 1 equivalent of trimethylamine $N$-oxide $\left(\mathrm{Me}_{3} \mathrm{NO} \cdot 2 \mathrm{H}_{2} \mathrm{O}\right)$ at room temperature (r.t.) for 40 minutes to afford the in-situ acetonitrile complex via oxidative abstraction of CO (decarbonylation) as shown in Scheme $1 .{ }^{42 c}$ Subsequent addition of $\mathrm{PPh}_{3}$ or $\mathrm{P}(\mathrm{OMe})_{3}$ affords the monosubstituted complexes $\mathrm{Fe}_{2}(\mathrm{CO})_{5}(\mathrm{~L})\left\{\mu-\left(\mathrm{SCH}_{2}\right)_{2}\right\} \mathrm{SnMe}_{2}(\mathrm{~L}=$ $\mathrm{PPh}_{3}$ (2) and $\mathrm{P}(\mathrm{OMe})_{3}(3)$ ) in moderate yields after stirring for 20 hour at r.t. (Scheme 1). Complexes 2 and 3 have been characterized by spectroscopic methods $\left({ }^{1} \mathrm{H} \mathrm{NMR},{ }^{13} \mathrm{C}\left\{{ }^{1} \mathrm{H}\right\} \mathrm{NMR}\right.$, ${ }^{31} \mathrm{P}\left\{{ }^{1} \mathrm{H}\right\} \mathrm{NMR}$ and IR), mass spectrometry, elemental analysis, and X-ray crystallography. 


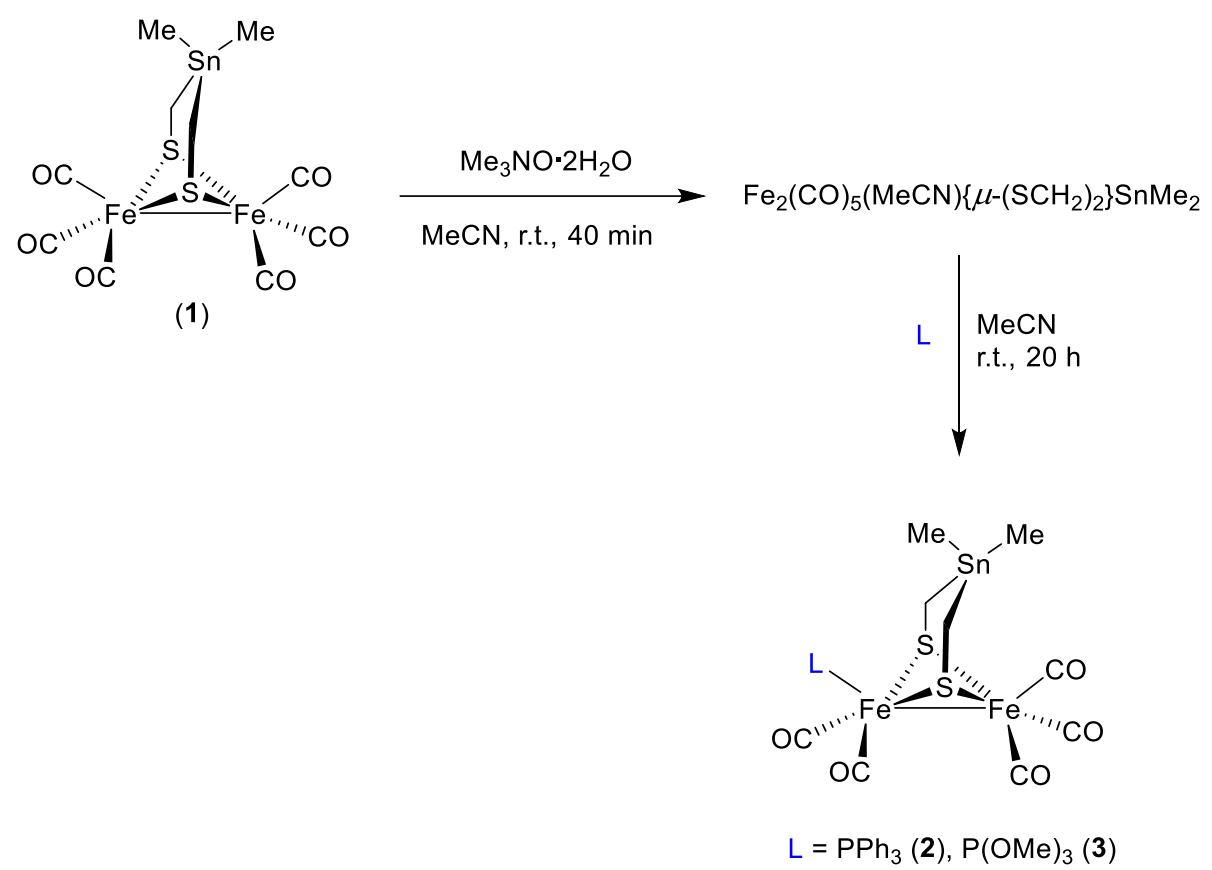

Scheme 1. Reaction pathway toward monosubstituted complexes $\mathbf{2}$ and $\mathbf{3 .}$

The IR spectrum of $\mathbf{2}$ in MeCN displays four $\mathrm{C} \equiv \mathrm{O}$ absorption bands, $v(\mathrm{CO})$, at 2040, 1980, 1952 and $1918 \mathrm{~cm}^{-1}$ while those of $\mathbf{3}$ stretch at 2045, 1990, 1972 and $1935 \mathrm{~cm}^{-1}$. These frequencies are markedly shifted toward lower values relative to those of $\mathbf{1}\left(2070,2032,1997 \text { and } 1989 \mathrm{~cm}^{-1}\right)^{38}$ by an average of $49 \mathrm{~cm}^{-1}$ and $36 \mathrm{~cm}^{-1}$ for $\mathbf{2}$ and $\mathbf{3}$, respectively. This difference in the shift of $v(\mathrm{CO})$ reflects the stronger electron donor ability of $\mathrm{PPh}_{3}$ in comparison to $\mathrm{P}(\mathrm{OMe})_{3}$. In comparison to 2 , the analogues complex $\mathrm{Fe}_{2}(\mathrm{CO})_{5}\left(\mathrm{PPh}_{3}\right)\left\{\mu-\left(\mathrm{SCH}_{2}\right)_{2}\right\} \mathrm{CMe}_{2}$ exhibits $\mathrm{C} \equiv \mathrm{O}$ absorption bands at higher wavenumbers; $v(\mathrm{CO})=2045,1981,1961$ and $1927 \mathrm{~cm}^{-1} \cdot{ }^{30}$ The disparity in the $v(\mathrm{CO})$ wavenumbers could be ascribed to an orbital interaction between the $\sigma \mathrm{C}-\mathrm{Sn}$ bond and the $\mathrm{S}$ lone pair, which brings about an increased electron richness at the $[2 \mathrm{Fe} 2 \mathrm{~S}]$ core. ${ }^{38}$ The ${ }^{1} \mathrm{H}$ NMR spectrum of 2 exhibits two doublets (AB spin system) for the diastereotopic methylene protons centered at $1.74\left({ }^{2} J\left\{{ }^{1} \mathrm{H}-{ }^{1} \mathrm{H}\right\}=12.0 \mathrm{~Hz}\right)$. In this ${ }^{1} \mathrm{H}$ NMR spectrum, the protons of the two $\mathrm{CH}_{3}$ groups resonate as a singlet at $0.21 \mathrm{ppm}$ with ${ }^{119} \mathrm{Sn}$ satellites $\left({ }^{2} J\left\{{ }^{119} \mathrm{Sn}-{ }^{1} \mathrm{H}\right\}=27.2 \mathrm{~Hz}\right)$. Additional signals are also detected in the range of 7.67-7.43 ppm for the phenyl protons. Moreover, the diastereotopic methylene protons of $\mathbf{3}$ resonate as two doublets ( $\mathrm{AB}$ spin system) centered at 1.74 $\operatorname{ppm}\left({ }^{2} J\left\{{ }^{1} \mathrm{H}-{ }^{1} \mathrm{H}\right\}=16.0 \mathrm{~Hz}\right)$. The methyl protons of the $\mathrm{P}(\mathrm{OMe})_{3}$ ligand show a doublet at 3.76 ppm $\left({ }^{3} J\left\{{ }^{31} \mathrm{P}-{ }^{1} \mathrm{H}\right\}=12.0 \mathrm{~Hz}\right)$. The ${ }^{1} \mathrm{H}$ NMR spectrum of $\mathbf{3}$ shows two singlets at 0.23 and $0.16 \mathrm{ppm}$ with $\mathrm{Sn}$ satellites $\left({ }^{2} J\left\{{ }^{119} \mathrm{Sn}-{ }^{1} \mathrm{H}\right\}=26.8 \mathrm{~Hz}\right)$ assigned to the $\mathrm{CH}_{3}$ groups attributing to a slower 
apical-basal ligand exchange in $\mathbf{3}$ than that in $\mathbf{2}$. Indeed, the ${ }^{31} \mathrm{P}\left\{{ }^{1} \mathrm{H}\right\}$ NMR spectrum (at r.t) of $\mathbf{2}$ displays a sharp singlet at $63.52 \mathrm{ppm}$ for the $\mathrm{PPh}_{3}$ ligand while that of $\mathbf{3}$ shows a broad signal at $175.09 \mathrm{ppm}$ for the $\mathrm{P}(\mathrm{OMe})_{3}$ ligand. This observation provides also an evidence for the apicalbasal site exchange such that this process is faster for the bulkier $\mathrm{PPh}_{3}{ }^{30}$ This broadness could be explained in terms of the fluxionality of the $\mathrm{Fe}(\mathrm{CO})_{2} \mathrm{P}(\mathrm{OMe})_{3}$ unit such that the $\mathrm{P}(\mathrm{OMe})_{3}$ substituent exchanges between the apical and basal positions. Upon cooling the sample to $-50{ }^{\circ} \mathrm{C}$ this signal splits into to singlets (182.7 and $171.0 \mathrm{ppm})$ indicating the presence of the basal and apical isomers (Figure S7). The ${ }^{13} \mathrm{C}\left\{{ }^{1} \mathrm{H}\right\}$ NMR spectra of both complexes display a singlet at 209.0 ppm for the carbonyl carbon atoms of the $\mathrm{Fe}(\mathrm{CO})_{3}$ unit whereas those carbons in the $\mathrm{Fe}(\mathrm{CO})_{2} \mathrm{P}(\mathrm{OMe})_{3}$ unit resonate as a doublet centered at $211.0 \mathrm{ppm}\left({ }^{2} J\left\{{ }^{31} \mathrm{P}^{13} \mathrm{C}\right\}=19 \mathrm{~Hz}\right)$. Furthermore, other signals are also detected as a doublet at $-6.6 \mathrm{ppm}$ for the $\mathrm{CH}_{3}$ group as well as a singlet at $2.2 \mathrm{ppm}$ for the methylene groups. The signals observed in the region of 128.5-135.5 ppm are attributed to the aromatic carbon atoms in $\mathbf{2}$ and a doublet centered at $52.2 \mathrm{ppm}$ for the carbon atoms in $\mathrm{P}(\mathrm{OMe})_{3}$ substituent of 3 .

\section{Molecular structures}

The diffusion of pentane into a $\mathrm{CH}_{2} \mathrm{Cl}_{2}$ solution of $\mathbf{2}$ or $\mathbf{3}$ at $-20{ }^{\circ} \mathrm{C}$ gave a suitable single crystal for X-ray diffraction studies. Figure 2 displays the molecular structures of $\mathbf{2}$ and $\mathbf{3}$ with ellipsoids drawn at the $50 \%$ probability level.
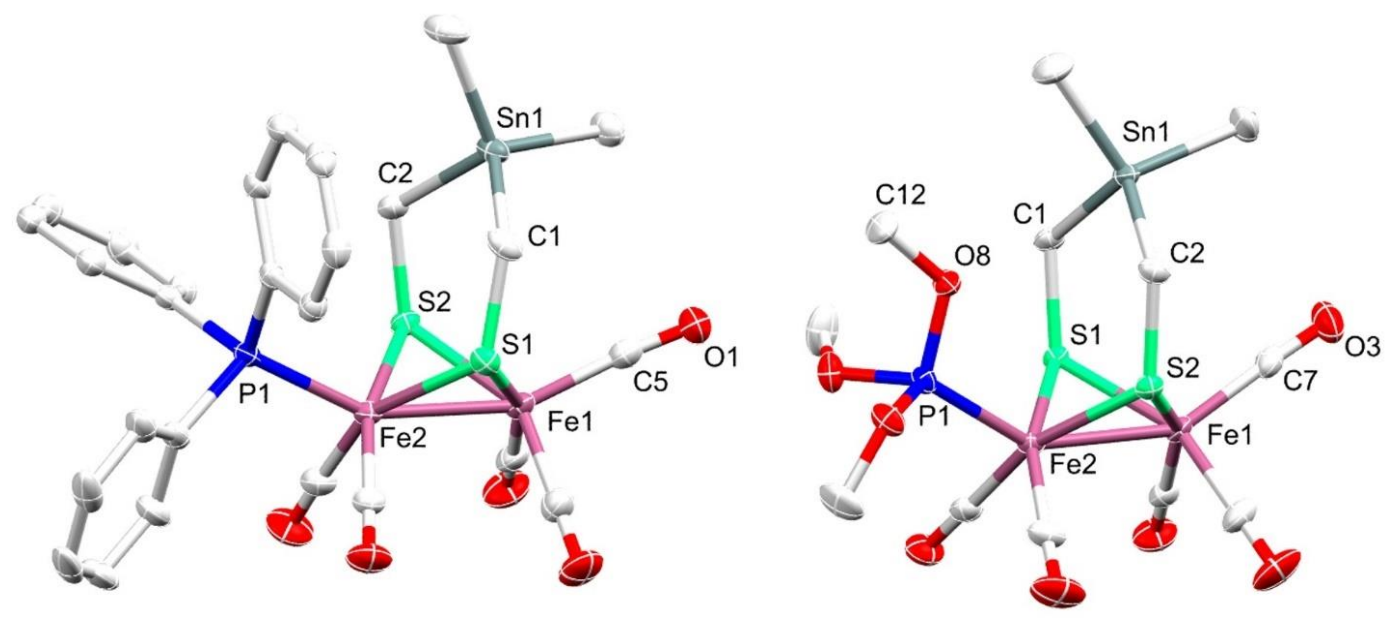

Figure 2. Molecular structures (50\% probability) of 2 (left) and $\mathbf{3}$ (right). Hydrogen atoms are omitted for clarity. 
The molecular structure of both complexes reveals the typical butterfly conformation of $\left[\mathrm{Fe}_{2} \mathrm{~S}_{2}\right]$ cluster core (Figure 2). In each complex, the two Fe atoms are bridged by the dithiolato $\left(\mathrm{SCH}_{2}\right)_{2} \mathrm{SnMe}_{2}$ ligand in which the bridgehead $\mathrm{Sn}$ atom is encircled by atoms in distorted tetrahedral fashion. The geometry of coordination around each iron center in both complexes can be best described as $\mathrm{Fe}(\mathrm{CO})_{3} \mathrm{~S}_{2}$ (or $\mathrm{Fe}(\mathrm{CO})_{2} \mathrm{PR}_{3} \mathrm{~S}_{2}$ ) square pyramid, with $\mathrm{Fe}$ slightly positioned outside the basal plane. The angle formed from the intersection between the $\mathrm{C}_{2} \mathrm{Sn}$ and $\mathrm{S}_{2} \mathrm{C}_{2}$ planes, so-called flap angle $\alpha$, equals $146.1^{\circ}$ or $160.3^{\circ}$ in 2 or 3 , respectively. These angles are smaller than that found in $\mathbf{1}\left(\alpha=173.6^{\circ}\right)$, which exhibits an almost planar $\mathrm{S}_{2} \mathrm{C}_{2} \mathrm{Sn}$ moiety. ${ }^{38}$ The fact that the flap angle in $\mathbf{3}$ deviates from $\alpha(\mathbf{1})=173.6^{\circ}$ more than the deviation in the case of $\mathbf{2}$ is attributed to the higher steric bulkiness of $\mathrm{PPh}_{3}$ in comparison to that of $\mathrm{P}(\mathrm{OMe})_{3}$. The $\mathrm{Fe}-\mathrm{Fe}$ bond length in complex 2 (2.5146(4) $\AA$ ) is slightly shorter than that in $\mathbf{1}(2.5249(5) \AA)$, which is in turn shorter than that in $\mathbf{3}$ (2.5322(4) $\AA$ ). The Fe2-P1 bond length in $\mathbf{2}(2.2342(6) \AA)$ is longer than that in $3(2.1576(6) \AA)$, owing to the higher $\pi$-acidity of $\mathrm{P}(\mathrm{OMe})_{3}$ compared to that $\mathrm{of} \mathrm{Ph}_{3} .{ }^{59}$

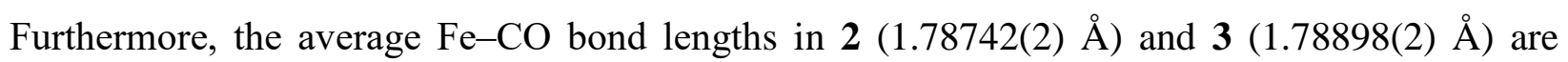
slightly shorter than that in complex 1 (1.802(3) $\AA$ ). These differences in Fe-CO bond lengths could be attributed to the higher $\mathrm{Fe} \rightarrow \mathrm{CO} \pi$-backbonding in $\mathbf{2}$ or $\mathbf{3}$ than that in $\mathbf{1 .}{ }^{38}$ The average Fe-S bond lengths in $\mathbf{2}(2.2737(6) \AA)$ and 3 (2.2633(6) ̊) are longer than that in $\mathbf{1}$ (2.2561(8) $\AA) .{ }^{38}$

\section{Protonation study}

The protophilicity of 2 and 3 towards $\mathrm{CF}_{3} \mathrm{CO}_{2} \mathrm{H}\left(\mathrm{p} K_{\mathrm{a}}{ }^{\mathrm{MeCN}}=12.65\right){ }^{60} \mathrm{HCl}\left(\mathrm{p} K_{\mathrm{a}}{ }^{\mathrm{MeCN}}=10.4\right)^{60}$ and $\mathrm{HBF}_{4} \cdot \mathrm{Et}_{2} \mathrm{O}\left(\mathrm{pK}_{\mathrm{a}}{ }^{\mathrm{MeCN}}=0.20\right)^{60}$ has been investigated by spectroscopic techniques. Complexes 2 and 3 were analyzed by attenuated total reflection Fourier-transform infrared (ATR FTIR) spectroscopy at ambient temperature and pressure. All experiments were conducted under anoxic conditions $\left(\mathrm{N}_{2}\right.$ atmosphere) and in the dark. Prior to the experiment, both complexes were dissolved in either pure $\mathrm{MeCN}$ and one equivalent of $\mathrm{CF}_{3} \mathrm{CO}_{2} \mathrm{H}, \mathrm{HBF}_{4} \cdot \mathrm{Et}_{2} \mathrm{O}$ or $\mathrm{HCl} .3 \mu \mathrm{L}$ of the solution were placed on the silicon crystal of the ATR cell and covered by a lid to minimize evaporation and protect the sample from stray light. Figure 3 shows the FTIR absorbance spectra in the CO region $\left(2200-1800 \mathrm{~cm}^{-1}\right)$ as well as second derivative spectra for an assignment of individual contributions. Under aprotic conditions (pure $\mathrm{MeCN}$ ), complexes $\mathbf{2}$ and $\mathbf{3}$ show a fairly similar band pattern with a single high-frequency band around $2040 \mathrm{~cm}^{-1}$ and a set of three CO 
bands between $1990-1918 \mathrm{~cm}^{-1}$ (see Table 1). In protic solvent, the presence of up to 10 equiv. $\mathrm{CF}_{3} \mathrm{CO}_{2} \mathrm{H}$ or $\mathrm{HCl}$ did not affect the $v(\mathrm{CO})$ bands of $\mathbf{2}$ and $\mathbf{3}$, which means that no protonation reaction took place. In the presence of 1 equiv. $\mathrm{HBF}_{4} \cdot \mathrm{Et}_{2} \mathrm{O}$, however, complexes $\mathbf{2}$ and $\mathbf{3}$ showed mean spectral up-shifts of $82 \pm 12 \mathrm{~cm}^{-1}$ and $22 \pm 7 \mathrm{~cm}^{-1}$, respectively. Despite the four-fold stronger up-shift of the $\mathrm{CO}$ frequencies in comparison to $\mathbf{3}$, the spectral pattern of $\mathbf{2}$ appeared to be well conserved. Both in the presence and absence of $\mathrm{HBF}_{4} \cdot \mathrm{Et}_{2} \mathrm{O}$, a strong band (s) is followed by another strong band with a spectral difference of $\sim 60 \mathrm{~cm}^{-1}$, a medium strong band (ms, spectral difference of $\sim 25 \mathrm{~cm}^{-1}$ ), and a weak band (w, spectral difference of $\sim 35 \mathrm{~cm}^{-1}$ ). The band pattern of 3 in protic solvent clearly differs from that of this complex in pure MeCN (Table 1).
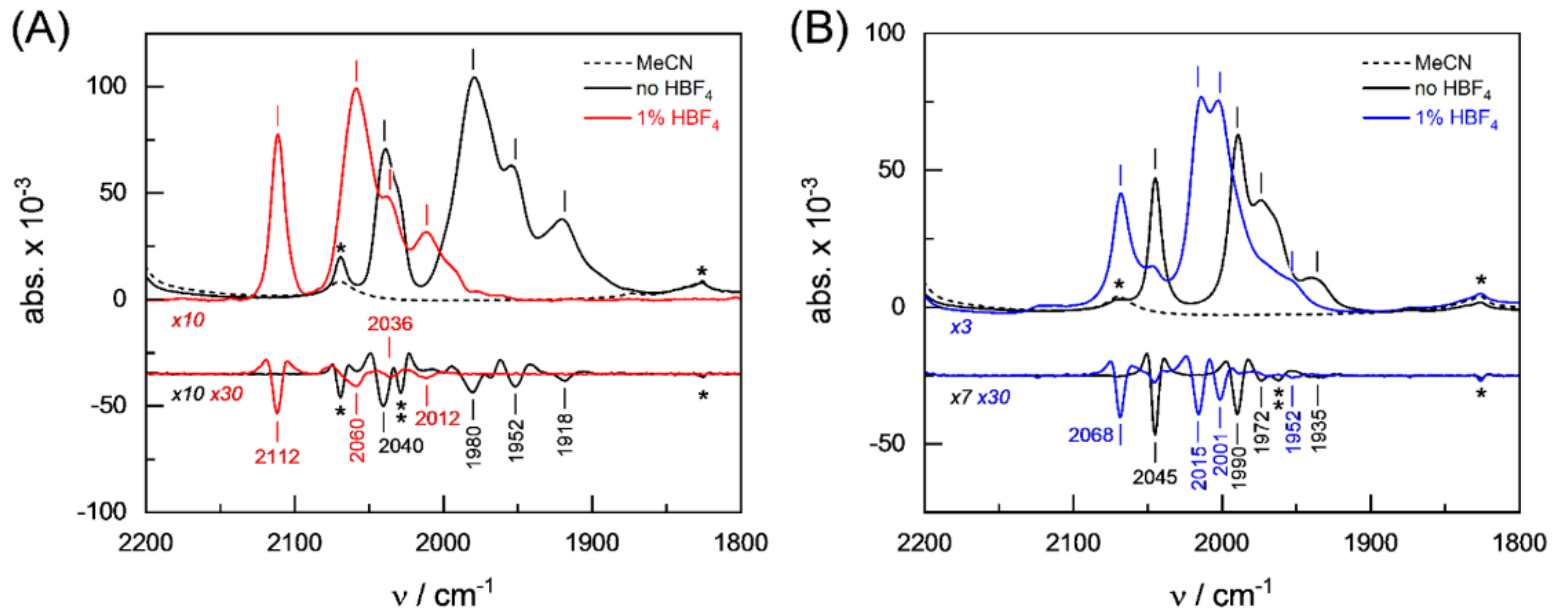

Figure 3. FTIR absorbance spectra of complexes $\mathbf{2}$ and 3. The CO frequency region is shown. (A) Complex 2 in solution with $\mathrm{MeCN}$ in the presence and absence of $\mathrm{HBF}_{4} \cdot \mathrm{Et}_{2} \mathrm{O}$ (red and black traces) and (B) Complex 3 in solution with $\mathrm{MeCN}$ in the presence and absence of $\mathrm{HBF}_{4} \cdot \mathrm{Et}_{2} \mathrm{O}$ (blue and black traces). The second derivate of absorbance spectra facilitated an unambiguous frequency assignment. Asterisk: spectral contribution from MeCN. Double asterisk in (A): unassigned shoulder at $2028 \mathrm{~cm}^{-1}$ of the strong CO band at $2040 \mathrm{~cm}^{-1}$ in the absence of $\mathrm{HBF}_{4} \cdot \mathrm{Et}_{2} \mathrm{O}$. Double asterisk in (B): unassigned shoulder at $1962 \mathrm{~cm}^{-1}$ of the strong CO band at $1972 \mathrm{~cm}^{-1}$ in the absence of $\mathrm{HBF}_{4} \cdot \mathrm{Et}_{2} \mathrm{O}$. Dashed spectra: $\mathrm{MeCN}$ reference. 
Table 1. CO stretching frequencies of complexes 2 and 3. Band intensity are weak (w), medium $(\mathrm{m})$, or strong (s).

\begin{tabular}{c|c|c|c|c|c}
\multirow{2}{*}{ Complex } & Solvent & \multicolumn{4}{|c}{$v_{\mathbf{c o}} / \mathbf{~ c m}^{-1}$ (band intensity) } \\
\hline \multirow{3}{*}{$\mathbf{2}$} & $\mathrm{MeCN}$ & $2040(\mathrm{~s})^{*}$ & $1980(\mathrm{~s})$ & $1952(\mathrm{~m})$ & $1918(\mathrm{w})$ \\
\cline { 2 - 6 } & $\mathrm{HBF}_{4} \cdot \mathrm{Et}_{2} \mathrm{O}$ & $2112(\mathrm{~s})$ & $2060(\mathrm{~s})$ & $2036(\mathrm{~m})$ & $2012(\mathrm{w})$ \\
\cline { 2 - 6 } & $\Delta$ & 72 & 79 & 84 & 94 \\
\hline \multirow{3}{*}{3} & $\mathrm{MeCN}^{3}$ & $2045(\mathrm{~s})$ & $1990(\mathrm{~s})$ & $1972(\mathrm{~m}) * *$ & $1935(\mathrm{w})$ \\
\cline { 2 - 6 } & $\mathrm{HBF}_{4} \cdot \mathrm{Et}_{2} \mathrm{O}$ & $2068(\mathrm{~s})$ & $2015(\mathrm{~s})$ & $2001(\mathrm{~s})$ & $1952(\mathrm{w})$ \\
\cline { 2 - 6 } & $\Delta$ & 23 & 25 & 29 & 17
\end{tabular}

* The band showed a shoulder at $2028 \mathrm{~cm}^{-1}$. ** The band showed a shoulder at $1962 \mathrm{~cm}^{-1}$

In conclusion, the ATR FTIR investigation of $\mathrm{CO}$ band frequencies suggests protonation (or hydride formation) at complexes 2 and 3 in the presence of the strong acid $\mathrm{HBF}_{4} \cdot \mathrm{Et}_{2} \mathrm{O}$. Analysis of the spectral region from $2600-2400 \mathrm{~cm}^{-1}$ indicated no specific differences for $\mathbf{2}$ and $\mathbf{3}$ between aprotic and protic solvent, which argues against sulfur protonation, at least under steady-state conditions (Figure S1). Indeed, this approach has been supported by testing the in-situ protonation reactions of 2 and 3 with 1 equiv. $\mathrm{HBF}_{4} \cdot \mathrm{Et}_{2} \mathrm{O}$ via ${ }^{1} \mathrm{H}$ and ${ }^{31} \mathrm{P}$ NMR techniques. The high-field region of the ${ }^{1} \mathrm{H}$ NMR spectra of $\mathbf{2}$ and $\mathbf{3}$ in the presence of $\mathrm{HBF}_{4} \cdot \mathrm{Et}_{2} \mathrm{O}$ show typical signals due to $\mu$-hydride species $\mathbf{2}(\boldsymbol{\mu}-\mathbf{H})^{+}$and $\mathbf{3}(\boldsymbol{\mu}-\mathbf{H})^{+}$. Unfortunately, decomposition accompanies the protonation of $\mathbf{2}$, which makes it complicated to interpret the spectra. The ${ }^{1} \mathrm{H}$ NMR spectrum of $\mathbf{3}$ in the presence of 1 equiv. $\mathrm{HBF}_{4} \cdot \mathrm{Et}_{2} \mathrm{O}$ is characterized by two sets of high-field doublets at -13.9 $\operatorname{ppm}\left(J\left\{{ }^{1} \mathrm{H}^{31} \mathrm{P}\right\}=6.0 \mathrm{~Hz}\right)$ and $-14.3 \mathrm{ppm}\left(J\left\{{ }^{1} \mathrm{H}^{3}{ }^{31} \mathrm{P}\right\}=24.0 \mathrm{~Hz}\right)$ with $c a 1: 2$ relative intensity. Since the coupling between the apical $\mathrm{PR}_{3}$ ligand and the $\mu$-hydride is typically weak or might not be observed, ${ }^{25,58}$ we assign the signals at $-13.9 \mathrm{ppm}$ and $-14.3 \mathrm{ppm}$ to the apical and basal isomers, respectively. Similarly, the ${ }^{31} \mathrm{P}$ NMR spectrum of the protonated complex $\mathbf{3}(\boldsymbol{\mu}-\mathbf{H})^{+}$displays two signals at $-154.8 \mathrm{ppm}$ and $-145.3 \mathrm{ppm}$ for the apical and basal isomers with relative intensity of ca. 1:2, respectively. Whereas $\mathrm{Fe}_{2}(\mathrm{CO})_{5} \mathrm{EPh}_{3}\left\{\mu-\left(\mathrm{SCH}_{2}\right)_{2}\right\}(\mathrm{E}=\mathrm{P}, \mathrm{As}, \mathrm{Sb})$ required excess amount of $\mathrm{HBF}_{4} \cdot \mathrm{Et}_{2} \mathrm{O}$ to protonate the $\mathrm{Fe}-\mathrm{Fe}$ bond, ${ }^{58 \mathrm{~d}}$ the presence of $\mathrm{Sn}$ atom in the dithiolato ligand of the complex makes the Fe-Fe bond more susceptible to protonation. 


\section{Electrochemistry}

Figure 4 shows the cyclic voltammetric reduction of $\mathbf{2}$ and $\mathbf{3}$ in comparison to that of $\mathbf{1}$ at a scan rate of $0.2 \mathrm{~V} \cdot \mathrm{s}^{-1}$. The cyclic voltammograms of $\mathbf{2}$ and $\mathbf{3}$ show irreversible cathodic peaks at $E_{\mathrm{pc}}=-$ $1.90 \mathrm{~V}$ (for 2) and $E_{\mathrm{pc}}=-2.15 \mathrm{~V}$ (for 3). These reduction potentials are shifted to more negative values by $220 \mathrm{mV}$ (for $\mathbf{2}$ ) and $470 \mathrm{mV}$ (for $\mathbf{3}$ ) in comparison to that of $\mathbf{1}\left(E_{\mathrm{pc}}=-1.68 \mathrm{~V}\right.$ ) due to the presence of the strong electron donating $\mathrm{PPh}_{3}$ and $\mathrm{P}(\mathrm{OMe})_{3}$ ligands. The less negative reduction potential of $\mathbf{2}$ compared to that of $\mathbf{3}$ is unexpected because $v(\mathrm{CO})$ wavenumbers are lower for 2. Furthermore, this order of reduction potentials disagrees with the ligand electrochemical parameters $\left(E_{\mathrm{L}}\right)$ determined by Lever for $\mathrm{PPh}_{3}\left(E_{\mathrm{L}}=0.39 \mathrm{~V}\right)$ and $\mathrm{P}(\mathrm{OMe})_{3}\left(E_{\mathrm{L}}=0.42 \mathrm{~V}\right) .{ }^{61} \mathrm{In}$ contrast to $\mathbf{1}$, increasing the scan rate achieves slight chemical reversibility for the reduction of $\mathbf{2}$ and 3 (Figures S11-13), suggesting a very fast follow-up decomposition. Indeed, the enhanced chemical reversibility of the reduction of $\mathbf{2}$ at higher scan rates is accompanied with appearance of small reduction even at $c a$. $-2.0 \mathrm{~V}$ (Figure S11), which might be related to reduction of the monoanionic species $\mathbf{2}^{-}$into dianionic one $\mathbf{2}^{\mathbf{2}}$.

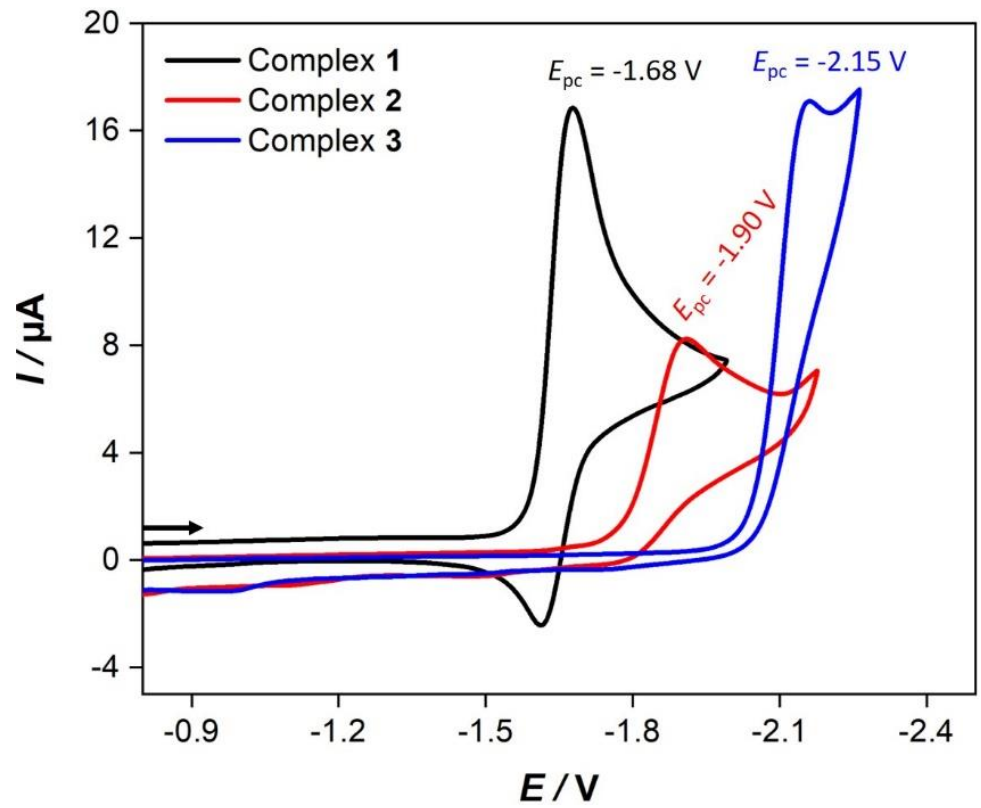

Figure 4. Cyclic voltammetry of $1.0 \mathrm{mM} \mathrm{1-3}$ in $\mathrm{CH}_{2} \mathrm{Cl}_{2}-\left[n-\mathrm{Bu}_{4} \mathrm{~N}\right]\left[\mathrm{BF}_{4}\right](0.1 \mathrm{M})$ solutions at 0.2 $\mathrm{V} / \mathrm{s}$ scan rate. The arrow indicates the scan direction. The potential $E$ is given in $\mathrm{V}$ and referenced to the $\mathrm{Fc}^{+} / \mathrm{Fc}$ couple. 
Evidence for the number of electrons involved in the reduction of the complexes could be obtained from studying the scan rate dependence of the current function $I_{\mathrm{p}} / c \cdot v^{1 / 2}\left(I_{\mathrm{p}}=\right.$ peak current, $c=$ concentration, $v=$ scan rate) ${ }^{62-70}$ While $I_{\mathrm{p}} / c \cdot v^{1 / 2}$ decreases towards a constant value as the scan rate increases in the cases of $\mathbf{1}^{38}$ and $\mathbf{3}$, the current function is found to be scan rate independent for $\mathbf{2}$ (Figure 5). These observations suggest an ECE cathodic process $(\mathrm{E}=$ Electron transfer and $\mathrm{C}=$ Chemical process) in the case of $\mathbf{1}$ and $\mathbf{3}$ while the reduction of $\mathbf{2}$ involves simple transfer of one electron. The intervening chemical process in the ECE mechanism is suppressed by increasing the scan rate.

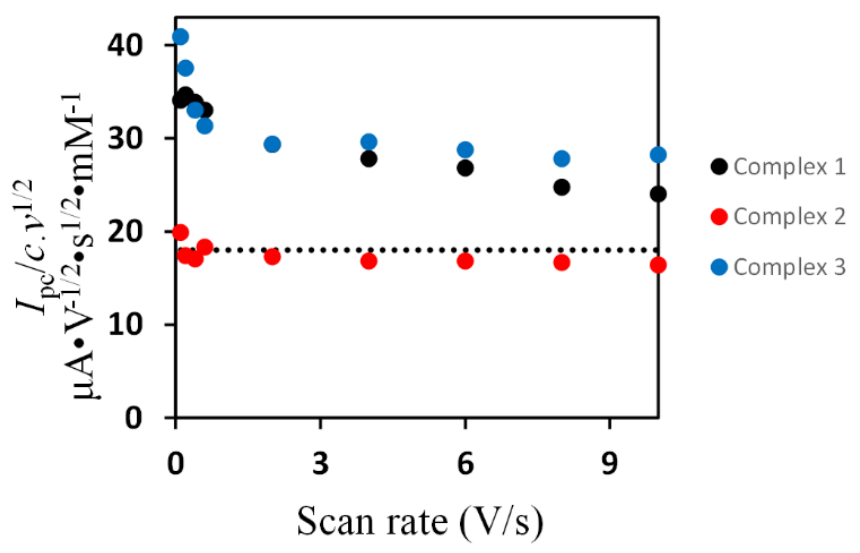

Figure 5. The scan rates dependence of the current function of the primary reduction peaks of 1.0 mM 1-3 in $\mathrm{CH}_{2} \mathrm{Cl}_{2}-\left[n-\mathrm{Bu}_{4} \mathrm{~N}\right]\left[\mathrm{BF}_{4}\right](0.1 \mathrm{M})$ solutions. Glassy carbon electrode $\left(A=0.0206 \mathrm{~cm}^{2}\right)$. The dashed line represents the current function expected for a one electron process assuming $D \approx$ $9 \times 10^{-6} \mathrm{~cm}^{2} \mathrm{~s}^{-1}$, a value calculated for various $[\mathrm{FeFe}]-H y d r o g e n a s e ~ m o d e l s$.

In the presence of $\mathrm{HBF}_{4} \cdot \mathrm{Et}_{2} \mathrm{O}$, the cyclic voltammograms display new reduction peaks at $960 \mathrm{mV}$ and $990 \mathrm{mV}$ less negative potentials in comparison to the primary reduction waves of $\mathbf{2}$ and $\mathbf{3}$, respectively, observed in the absence of acid. These new reduction waves are attributed to the reduction of the protonated form of $\mathbf{2}$ and $\mathbf{3}$. Similar shifts have been reported and attributed to the protonation of the $\mathrm{Fe}-\mathrm{Fe}$ bond in various complexes. ${ }^{55} \mathrm{In}$ contrast, the presence of strong acids $\left(\mathrm{HBF}_{4} \cdot \mathrm{Et}_{2} \mathrm{O}\right.$ or $\left.\mathrm{CF}_{3} \mathrm{SO}_{3} \mathrm{H}\right)$ has only led to small anodic shift of the reduction wave of $\mathbf{1}$, which is typical thermodynamic effect resulting from protonation of the reduced species of $1 .{ }^{38}$ Indeed, direct reduction of $\mathrm{HBF}_{4} \cdot \mathrm{Et}_{2} \mathrm{O}$ at the electrode is significant at high concentrations and hence the 
measurements were conducted only at low acid concentrations. While the cyclic voltammetry of $\mathbf{3}$ (Figure 6) displays three distinct reduction waves $\left(E_{\mathrm{p}}=-1.17 \mathrm{~V},-1.64 \mathrm{~V}\right.$ and $\left.-2.14 \mathrm{~V}\right)$ in the presence of 2-4 equiv. $\mathrm{HBF}_{4} \cdot \mathrm{Et}_{2} \mathrm{O}$, the situation is more complicated in the case of 2 (Figure S14) as an overlap of reduction waves is observed. The current of these three reduction events increases very slightly as the equiv. $\left[\mathrm{HBF}_{4} \cdot \mathrm{Et}_{2} \mathrm{O}\right] /[3]$ increases up to 4.

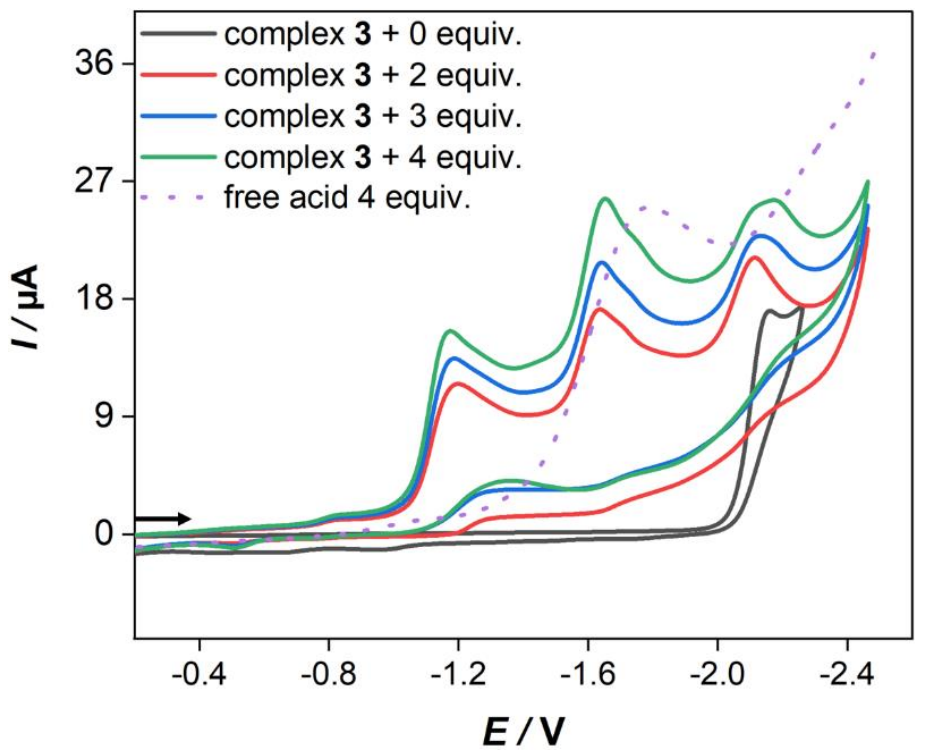

Figure 6. Cyclic voltammetry $\left(0.2 \mathrm{~V} \cdot \mathrm{s}^{-1}\right)$ of $1.0 \mathrm{mM} \mathrm{Fe} 2(\mathrm{CO})_{5}\left(\mathrm{P}(\mathrm{OMe})_{3}\right)\left\{\mu-\left(\mathrm{SCH}_{2}\right)_{2}\right\} \mathrm{SnMe}_{2}(3)$ in $\mathrm{CH}_{2} \mathrm{Cl}_{2}-\left[n-\mathrm{Bu}_{4} \mathrm{~N}\right]\left[\mathrm{BF}_{4}\right](0.1 \mathrm{M})$ at $\left[\mathrm{HBF}_{4} \cdot \mathrm{Et}_{2} \mathrm{O}\right] /[3]=0-4$. Glassy carbon electrode (diameter $=$ $1.6 \mathrm{~mm})$. Potential $E$ is given in volts $(\mathrm{V})$ and referenced to $\mathrm{Fc}^{+} / \mathrm{Fc}$ couple. The arrows indicate the scan direction.

\section{Conclusions}

We have reported on the synthesis of $\mathrm{Fe}_{2}(\mathrm{CO})_{5}(\mathrm{~L})\left\{\mu\right.$-( $\left.\left(\mathrm{SCH}_{2}\right)_{2}\right\} \mathrm{SnMe}_{2}\left(\mathrm{~L}=\mathrm{PPh}_{3}(2)\right.$ and $\mathrm{P}(\mathrm{OMe})_{3}$ (3)) via oxidative abstraction of $\mathrm{CO}$ from $\mathrm{Fe}_{2}(\mathrm{CO})_{6}\left\{\mu-\left(\mathrm{SCH}_{2}\right)_{2}\right\} \mathrm{SnMe}_{2}(\mathbf{1})$ followed by addition of $\mathrm{PPh}_{3}$ or $\mathrm{P}(\mathrm{OMe})_{3}$ (Scheme 1). The variable temperature ${ }^{1} \mathrm{H}$ and ${ }^{31} \mathrm{P}\left\{{ }^{1} \mathrm{H}\right\}$ NMR spectroscopic techniques reveals the presence of two isomers of 3 at $-50^{\circ} \mathrm{C}$ with apically and basally oriented $\mathrm{P}(\mathrm{OMe})_{3}$ ligand. In contrast, 2 and 3 exhibit only the apical orientation of $\mathrm{PPh}_{3}$ or $\mathrm{P}(\mathrm{OMe})_{3}$ in the solid state (Figure 2). While 1 exhibits an almost planar molecular structure $\left(\alpha=173.6^{\circ}\right)$, the 
introduction of $\mathrm{PPh}_{3}$ or $\mathrm{P}(\mathrm{OMe})_{3}$ into the apical position in $\mathbf{2}$ or $\mathbf{3}$, respectively, results in a deviation from planarity. The smaller flap angle measured in $\mathbf{3}\left(\alpha=146.1^{\circ}\right)$ compared to that in the case of $2\left(\alpha=160.3^{\circ}\right)$ is attributed to the higher steric demand of the $\mathrm{PPh}_{3}$ with respect to that of $\mathrm{P}(\mathrm{OMe})_{3}$. Although $\mathrm{PPh}_{3}$ is stronger electron donor ligand than $\mathrm{P}(\mathrm{OMe})_{3}$ as evident from the $v(\mathrm{CO})$ wavenumbers of $\mathbf{2}$ and $\mathbf{3}$, the reduction potentials of these complexes show an unexpected trend; $E_{\mathrm{pc}}=-1.90 \mathrm{~V}$ (for 2) and $E_{\mathrm{pc}}=-2.15 \mathrm{~V}$ (for 3). This unexpected reductive behavior might be attributed to chemical processes intervening in the electron transfer. In contrast to the case of 1, the cyclic voltammetry of $\mathbf{2}$ or $\mathbf{3}$ show that protonation precedes electron transfer due to the presence of the strong electron donating ligands. By means of spectroscopic techniques, the protonation of $\mathbf{2}$ and $\mathbf{3}$ is proven to take place at the Fe-Fe bond leading to $\mu$-hydride species. Only 1 equiv of $\mathrm{HBF}_{4} \cdot \mathrm{Et}_{2} \mathrm{O}$ is sufficient to protonate $\mathbf{2}$ and $\mathbf{3}$ at the Fe-Fe bond forming $\mathbf{2}(\boldsymbol{\mu}-\mathbf{H})^{+}$and $\mathbf{3}(\boldsymbol{\mu}-\mathbf{H})^{+}$species that is triggered not only by the presence of the $\mathrm{PR}_{3}$ ligands, but also via the filledfilled interaction between the C-Sn bond and the neighboring lone pair of the $\mu$-S atoms.

\section{Experimental}

\section{Materials and techniques}

All reactions were performed using standard Schlenk and vacuum-line techniques under an inert gas (nitrogen). The ${ }^{1} \mathrm{H},{ }^{13} \mathrm{C}\left\{{ }^{1} \mathrm{H}\right\}$ and ${ }^{31} \mathrm{P}\left\{{ }^{1} \mathrm{H}\right\}$ spectra were recorded with a Bruker Avance 400 $\mathrm{MHz}$ spectrometer. Chemical shifts are given in parts per million with references to internal $\mathrm{SiMe}_{4}$ $\left({ }^{1} \mathrm{H},{ }^{13} \mathrm{C}\right)$. External standard $85 \% \quad \mathrm{H}_{3} \mathrm{PO}_{4}$ was used as a reference for ${ }^{31} \mathrm{P}\left\{{ }^{1} \mathrm{H}\right\}$ spectral measurements. The mass spectrum was recorded with Finnigan MAT SSQ 710 instrument. Elemental analysis was performed with a Leco CHNS-932 apparatus. TLC was performed by using Merck TLC aluminum sheets (Silica gel 60 F254). Solvents from Fisher Scientific and other chemicals from Across and Aldrich were used without further purification. All solvents were dried and distilled prior to use according to standard methods. Complex $\mathbf{1}$ was synthesized according to the known literature method. ${ }^{38}$

\section{Electrochemistry}

Corrections for the $i R$ drop were performed for all experiments. Cyclic voltammetric measurements were conducted in three-electrode technique [glassy carbon disk (diameter $=1.6 \mathrm{~mm}$ ) as working electrode, $\mathrm{Ag} / \mathrm{Ag}^{+}$in $\mathrm{MeCN}$ as reference electrode, $\mathrm{Pt}$ wire as counter 
electrode] using a Reference 600 Potentiostat (Gamry Instruments). All experiments were performed in $\mathrm{CH}_{2} \mathrm{Cl}_{2}$ solutions (concentration of the complexes $1.0 \mathrm{mM}$ ) containing $0.1 \mathrm{M}$ [ $n$ $\left.\mathrm{Bu}_{4} \mathrm{~N}\right]\left[\mathrm{BF}_{4}\right]$ at room temperature. The solutions were purged with $\mathrm{N}_{2}$ and a stream of it was maintained over the solutions during the measurements. The vitreous carbon disk was polished on a felt tissue with alumina before each measurement. All potential values reported in this paper are referenced to the potential of the ferrocenium/ferrocene $\left(\mathrm{Fc}^{+} / \mathrm{Fc}\right)$ couple.

\section{X-ray crystal structure analysis}

The intensity data for the compounds were collected on a Nonius KappaCCD diffractometer using graphite-monochromated Mo-K $\alpha$ radiation. Data were corrected for Lorentz and polarization effects; absorption was taken into account on a semi-empirical basis using multiple-scans. ${ }^{71-73}$ The structures were solved by direct methods (SHELXS) ${ }^{74}$ and refined by full-matrix least squares techniques against $\mathrm{Fo}^{2}$ SHELXL-2018). ${ }^{75}$ The hydrogen atoms bonded to the methine-groups $\mathrm{C} 1$ and $\mathrm{C} 2$ of compound $\mathbf{3}$ were located by difference Fourier synthesis and refined isotropically. All other hydrogen atoms were included at calculated positions with fixed thermal parameters. All non-hydrogen atoms were refined anisotropically. ${ }^{75}$ MERCURY was used for structure representations. ${ }^{76}$

Crystal Data for 2: $\mathrm{C}_{27} \mathrm{H}_{25} \mathrm{Fe}_{2} \mathrm{O}_{5} \mathrm{PS}_{2} \mathrm{Sn}, \mathrm{Mr}=754.95$ gmol $^{-1}$, red-brown prism, size $0.042 \times 0.038$ x $0.032 \mathrm{~mm}^{3}$, triclinic, space group $\mathrm{P} \overline{1}, \mathrm{a}=9.7998(2), \mathrm{b}=10.5057(2), \mathrm{c}=16.7575(3) \AA, \alpha=$ 106.986(1), $\beta=91.930(1), \gamma=114.973(1)^{\circ}, \mathrm{V}=1470.99(5) \AA^{3}, \mathrm{~T}=-140{ }^{\circ} \mathrm{C}, \mathrm{Z}=2, \rho_{\text {calcd. }}=1.704$ $\mathrm{gcm}^{-3}, \mu\left(\mathrm{Mo}-\mathrm{K}_{\alpha}\right)=20.47 \mathrm{~cm}^{-1}$, multi-scan, transmin: 0.6677, transmax: 0.7456, $\mathrm{F}(000)=752$, 9131 reflections in $\mathrm{h}(-12 / 12), \mathrm{k}(-13 / 13), 1(-21 / 18)$, measured in the range $2.272^{\circ} \leq \Theta \leq 27.362^{\circ}$, completeness $\Theta \max =99.2 \%, 6587$ independent reflections, $\mathrm{R}_{\mathrm{int}}=0.0142,6284$ reflections with $\mathrm{F}_{\mathrm{o}}>4 \sigma\left(\mathrm{F}_{\mathrm{o}}\right), 345$ parameters, 0 restraints, $\mathrm{R} 1_{\mathrm{obs}}=0.0235, \mathrm{wR}^{2}{ }_{\mathrm{obs}}=0.0517, \mathrm{R} 1_{\text {all }}=0.0254, \mathrm{wR}^{2}{ }_{\text {all }}$ $=0.0533, \mathrm{GOOF}=1.070$, largest difference peak and hole: $0.388 /-0.491 \mathrm{e}^{-3}$.

Crystal Data for 3: $\mathrm{C}_{12} \mathrm{H}_{19} \mathrm{Fe}_{2} \mathrm{O}_{8} \mathrm{PS}_{2} \mathrm{Sn}, \mathrm{Mr}=616.75$ gmol $^{-1}$, red-brown prism, size $0.046 \times 0.042$ x $0.038 \mathrm{~mm}^{3}$, triclinic, space group P $\overline{1}, \mathrm{a}=9.6675(3), \mathrm{b}=10.2531(3), \mathrm{c}=12.5768(3) \AA, \alpha=$ 102.077(1), $\beta=103.608(1), \gamma=109.654(1)^{\circ}, \mathrm{V}=1082.95(5) \AA^{3}, \mathrm{~T}=-140{ }^{\circ} \mathrm{C}, \mathrm{Z}=2, \rho_{\text {calcd. }}=1.891$ $\mathrm{gcm}^{-3}, \mu\left(\mathrm{Mo}-\mathrm{K}_{\alpha}\right)=27.65 \mathrm{~cm}^{-1}$, multi-scan, transmin: 0.6397, transmax: 0.7456, $\mathrm{F}(000)=608$, 6883 reflections in $\mathrm{h}(-12 / 12), \mathrm{k}(-13 / 8), \mathrm{l}(-16 / 16)$, measured in the range $2.438^{\circ} \leq \Theta \leq 27.101^{\circ}$, 
completeness $\Theta \max =99.2 \%, 4731$ independent reflections, $\mathrm{R}_{\text {int }}=0.0149,4560$ reflections with $\mathrm{F}_{\mathrm{o}}>4 \sigma\left(\mathrm{F}_{\mathrm{o}}\right), 256$ parameters, 0 restraints, $\mathrm{R} 1_{\mathrm{obs}}=0.0200, \mathrm{wR}^{2}{ }_{\mathrm{obs}}=0.0467, \mathrm{R} 1_{\text {all }}=0.0211, \mathrm{wR}_{\text {all }}^{2}$ $=0.0474, \mathrm{GOOF}=1.099$, largest difference peak and hole: $0.457 /-0.389 \mathrm{e} \AA^{-3}$.

General procedure for the synthesis of $\mathrm{Fe}_{2}(\mathrm{CO})_{5}(\mathrm{~L})\left\{\mu-\left(\mathrm{SCH}_{2}\right)_{2} \mathrm{SnMe}_{2}\right\}\left(\mathrm{L}=\mathrm{PPh}_{3}\right.$ and $\left.\mathbf{P}(\mathbf{O M e})_{3}\right)$.

To a solution of 1 in $\mathrm{MeCN}(25 \mathrm{~mL}), 2$ equiv. $\mathrm{Me}_{3} \mathrm{NO} \cdot{ }_{2} \mathrm{H}_{2} \mathrm{O}$ were added to give the respective nitrile complex within $40 \mathrm{~min}$, visible by darkening of the red solution. Subsequently, 1 equiv. L was added and the reaction mixture was stirred at r.t. for $20 \mathrm{~h}$. The resulting red solution was then treatment with small amount of silica and the solvent was evaporated using vacuum transfer line. The residue was purified by column chromatography using $\mathrm{CH}_{2} \mathrm{Cl}_{2} / \mathrm{Hexane}(1 / 5)$ as eluent. The complexes were collected from the first red-orange band and the solvent was evaporated to give the complexes as red-orange solids.

$\left.\mathrm{Fe}_{2}\left(\mathbf{C O}_{5}(\mathbf{P P h})_{2} \boldsymbol{\mu} \text {-(SCH}\right)_{2}\right\} \mathbf{S n M e}_{2}$ (2). Complex $1(100 \mathrm{mg}, 0.19 \mathrm{mmol})$ was treated with $\mathrm{Me}_{3} \mathrm{NO} \cdot{ }_{2} \mathrm{H}_{2} \mathrm{O}(43 \mathrm{mg}, 0.38 \mathrm{mmol})$ and $\mathrm{PPh}_{3}(50 \mathrm{mg}, 0.19 \mathrm{mmol})$ according to the general procedure. Yield: $68 \%$ (100 mg, $0.13 \mathrm{mmol}$ ). $\mathrm{C}_{27} \mathrm{H}_{25} \mathrm{Fe}_{2} \mathrm{O}_{5} \mathrm{PSnS}_{2}$ : C, 42.95; H, 3.34; S, 8.49. Found: C, 42.77; H, 3.41; S, 8.22. DEI-MS (m/z): $700[\mathrm{M}-2 \mathrm{CO}]^{+}, 672[\mathrm{M}-3 \mathrm{CO}]^{+}, 644[\mathrm{M}-$ $4 \mathrm{CO}]^{+}$and $616[\mathrm{M}-5 \mathrm{CO}]^{+} . \mathrm{IR}(\mathrm{MeCN}): 2040(\mathrm{~s}), 1980(\mathrm{~s}), 1952(\mathrm{~ms})$ and $1918(\mathrm{w}) \mathrm{cm}^{-1} \cdot{ }^{31} \mathrm{P}\left\{{ }^{1} \mathrm{H}\right\}$ NMR (162 MHz, $\left.\mathrm{CDCl}_{3}\right): \delta 63.52\left(\mathrm{PPh}_{3}\right) .{ }^{13} \mathrm{C}\left\{{ }^{1} \mathrm{H}\right\} \mathrm{NMR}\left(100 \mathrm{MHz}, \mathrm{CDCl}_{3}\right): \delta-6.6\left(\mathrm{CH}_{2} \mathrm{SnCH}_{3}\right)$, $2.2\left(\mathrm{CH}_{2} \mathrm{SnCH}_{3}\right), 128.5-135.5(\mathrm{Ph})$ and $209.0(\mathrm{CO}) .{ }^{1} \mathrm{H}$ NMR $\left(400 \mathrm{MHz}, \mathrm{CDCl}_{3}\right): \delta 0.21(\mathrm{~s}, 6 \mathrm{H}$, $\left.J\left\{S n-{ }^{l} H\right\}=27.2 \mathrm{~Hz}, \mathrm{Sn}\left(\mathrm{CH}_{3}\right)_{2}\right), 1.71\left(\mathrm{~d}, 2 \mathrm{H}, J\left\{{ }^{1} H^{-1}{ }^{1} H\right\}=8.0 \mathrm{~Hz}, \mathrm{CH}_{2} \mathrm{Sn}\right), 1.76\left(\mathrm{~d}, 2 \mathrm{H}, J{ }^{1} H^{-}{ }^{1} H\right\}$ $\left.=8.0 \mathrm{~Hz}, \mathrm{CH}_{2} \mathrm{Sn}\right)$ and $7.43-7.67(\mathrm{~m}, 15 \mathrm{H})$.

$\mathrm{Fe}_{2}(\mathbf{C O})_{5}\left(\mathbf{P}(\mathbf{O M e})_{3}\right)\left\{\boldsymbol{\mu}-\left(\mathbf{S C H}_{2}\right)_{2}\right\} \mathrm{SnMe}_{2}(3)$. Complex 1 (100 mg, $\left.0.19 \mathrm{mmol}\right)$ was treated with $\mathrm{Me}_{3} \mathrm{NO} \cdot{ }_{2} \mathrm{H}_{2} \mathrm{O}(43 \mathrm{mg}, 0.38 \mathrm{mmol})$ and $\mathrm{P}(\mathrm{OMe})_{3}(24 \mathrm{mg}, 0.19 \mathrm{mmol})$ according to the general procedure. Yield: $81 \%$ (95 mg, 0.15 mmol. $\mathrm{C}_{12} \mathrm{H}_{19} \mathrm{Fe}_{2} \mathrm{O}_{8} \mathrm{PSnS}_{2}$ : C, 23.37; H, 3.10; S, 10.40. Found: C, 23.80; H, 3.20; S, 10.23. DEI-MS (m/z): $590\left[\mathrm{M}-\mathrm{CO}^{+}, 562[\mathrm{M}-2 \mathrm{CO}]^{+}, 534[\mathrm{M}-3 \mathrm{CO}]^{+}\right.$, $506[\mathrm{M}-4 \mathrm{CO}]^{+}$and $478[\mathrm{M}-5 \mathrm{CO}]^{+}$IR $(\mathrm{MeCN}):$ 2045(s), 1990(s), 1972(ms), 1935(w) $\mathrm{cm}^{-1}$. ${ }^{31} \mathrm{P}\left\{{ }^{1} \mathrm{H}\right\}$ NMR (162 MHz, $\left.\mathrm{CDCl}_{3}\right): \delta$ 175.09, (298 K) (s, br, $\left.\mathrm{P}(\mathrm{OMe})_{3}\right) ; 182.72,170.99(223 \mathrm{~K})$ (2s, P(OMe $\left.)_{3}\right){ }^{13} \mathrm{C}\left\{{ }^{1} \mathrm{H}\right\}$ NMR (100 MHz, $\left.\mathrm{CDCl}_{3}\right): \delta-6.6\left(\mathrm{CH}_{2} \mathrm{SnCH}_{3}\right), \quad 2.2\left(\mathrm{CH}_{2} \mathrm{SnCH}_{3}\right), 52.2$ $\left(\mathrm{P}(\mathrm{OMe})_{3}\right), 209.0\left(\mathrm{Fe}(\mathrm{CO})_{3}\right)$ and $211.0\left(\mathrm{~d}, \mathrm{Fe}(\mathrm{CO})_{2} \mathrm{P}(\mathrm{OMe})_{3}\right) .{ }^{1} \mathrm{H} \mathrm{NMR}\left(400 \mathrm{MHz}, \mathrm{CDCl}_{3}\right): \delta 0.18$ 
$\left(\mathrm{s}, 6 \mathrm{H}, J\left\{S n-{ }^{l} H\right\}=26.8 \mathrm{~Hz}, \mathrm{Sn}\left(\mathrm{CH}_{3}\right)_{2}\right), 1.65\left(\mathrm{~d}, 2 \mathrm{H} J\left\{{ }^{1} \mathrm{H}-{ }^{1} \mathrm{H}\right\}=8.0 \mathrm{~Hz}, \mathrm{CH}_{2} \mathrm{Sn}\right), 1.78\left(\mathrm{~d}, 2 \mathrm{H}, J_{\{\mathrm{H}-}\right.$ $\left.\mathrm{H}\}=8.0 \mathrm{~Hz}, \mathrm{CH}_{2} \mathrm{Sn}\right)$ and $3.75\left(\mathrm{~d}, 9 \mathrm{H}, J\left\{{ }^{1} \mathrm{H}-\mathrm{P}\right\}=12.0 \mathrm{~Hz}, \mathrm{P}(\mathrm{OMe})_{3}\right)$.

\section{Conflicts of interest}

There are no conflicts to declare.

\section{Acknowledgments}

W.W. and H.A.-F. are thankful to Deutsche Forschungsgemeinschaft (DFG) for supporting this work (WE 1179/11-1). H.A.-F. thanks the deanship of research, Al-Zaytoonah University of Jordan for financial support (Grant No. 18/2018-2019). S.T.S. acknowledges support by the DFG through the priority program 1927 (grant agreement No. 1554/5-1).

\section{Supporting Information}

Crystallographic data (excluding structure factors) has been deposited with the Cambridge Crystallographic Data Centre as supplementary publication CCDC-2026923 for 2, and CCDC2026924 for 3 . Copies of the data can be obtained free of charge on application to CCDC, 12 Union Road, Cambridge CB2 1EZ, UK [E- mail: deposit@ccdc.cam.ac.uk]. All NMR spectra are furnished in the electronic supplementary information.

\section{References}

1 D. J. Wuebbles and A. K. Jain, Fuel Process. Technol., 2001, 71, 99.

2 S. Dunn, Int. J. Hydrogen Energy, 2002, 27, 235.

3 M. Momirlan and T. N. Veziroglu, Int. J. Hydrogen Energy, 2005, 30, 795.

4 S. Shima, O. Pilak, S. Vogt, M. Schick, M. S. Stagni, W. M. Klaucke, E. Warkentin, R. K. Thauer and U. Ermler, Science, 2008, 321, 572.

5 J. G. Canadell, C. Le Quere, M. R. Raupach, C. B. Field, E. T. Buitenhuis, P. Ciais, T. J. Conway, N. P Gillett, R. A. Houghton and G. Marland, Proc. Natl. Acad. Sci., 2007, 104, 18866.

6 M. Sensi, C. Baffert, C. Greco, G. Caserta, C. Gauquelin, L. Saujet, M. Fontecave, S. Roy, V. Artero, P. Soucaille, I. Meynial-Salles, H. Bottin, L. de Gioia, V. Fourmond, C. Léger and L. Bertini, J. Am. Chem. Soc., 2016, 138, 13612. 
7 M. W. Adams, Biochim. Biophys. Acta., 1990, 1020, 115.

8 M. Frey, ChemBioChem., 2002, 3, 153.

9 C. Tard and C. J. Pickett, Chem Rev., 2009, 109, 2245.

10 W. Lubitz, H. Ogata, O. Rüdiger and E. Reijerse, Chem. Rev., 2014, 114, 4081.

11 J. W. Peters, W. N. Lanzilotta, B. J. Lemon and L. C. Seefeldt, Science, 1998, 282, 1853.

12 Y. Nicolet, A. L. de Lacey, X. Vernede, V. M. Fernandez, E. C. Hatchikian and J. C. Fontecilla-Camps, J. Am. Chem. Soc., 2001, 123, 1596.

13 (a) A. Silakov, B. Wenk, E. Reijerse and W. Lubitz, Phys. Chem. Chem. Phys., 2009, 11, 6592; (b) G. Berggren, A. Adamska, C. Lambertz, T. R. Simmons, J. Esselborn, M. Atta, S. Gambarelli, J. M. Mouesca, E. Reijerse, W. Lubitz, T. Happe, V. Artero and M. Fontecave, Nature, 2013, 499, 66.

14 (a) M. Haumann and S. T. Stripp, Acc. Chem. Res., 2018, 51, 1755; (b) H. Land, M. Senger, G. Berggren S. T. Stripp, ACS Catal., 2020, 10, 7069.

15 Y. Li and T. B. Rauchfuss, Chem. Rev., 2016, 116, 7043.

16 T. R. Simmons, G. Berggren, M. Bacchi, M. Fontecave and V. Artero, Coord. Chem. Rev., 2014, 270-271, 127.

17 S. Gao, Y. Liu, Y. Shao, D. Jiang and Q. Duan, Coord. Chem. Rev., 2020, 402, 213081.

18 W. Lubitz, H. Ogata, O. Rüdiger and E. Reijerse, Chem. Rev., 2014, 114, 4081.

19 H. Abul-Futouh, L. R. Almazahreh, M. K. Harb, H. Görls, M. El-khateeb and W. Weigand, Inorg. Chem., 2017, 56, 10437.

20 H. Abul-Futouh, A. Q. Daraosheh, J. Windhager, H. Görls and W. Weigand, Polyhedron, $2019, \mathbf{1 7 4}, 114155$.

21 J. D. Lawrence, H. Li, T. B. Rauchfuss, M. Bénard and M. Rohmer, Angew. Chem. Int. Ed., 2001, 40, 1768.

22 M. Watanabe, K. Goto, T. Miyazaki, M. Shibahara, Y. J. Chang, T. J. Chow and T. Ishihara, New J. Chem., 2019, 43, 13810.

23 H. Abul-Futouh, A. Skabeev, D. Botteri, Y. Zagranyarski, H. Görls, W. Weigand and K. Peneva, Organometallics, 2018, 37, 3278.

24 H. Abul-Futouh, Y. Zagranyarski, C. Müller, M. Schulz, S. Kupfer, H. Görls, M. Elkhateeb, S. Gräfe, B. Dietzek, K. Peneva and W. Weigand, Dalton Trans., 2017, 46, 11180. 
25 M. E. Carroll, B. E. Barton, T. B. Rauchfuss and P. J. Carroll, J. Am. Chem. Soc., 2012, 134, 18843.

26 J. Hou, X. Peng, J. Liu, Y. Gao, X. Zhao, S. Gao and K. Han, Eur. J. Inorg. Chem., 2006, 4679.

27 W.-G. Wang, H.-Y. Wang, G. Si, C.-H. Tung and L.-Z. Wu, Dalton Trans., 2009, 2712.

28 Y. Si, C. Ma, M. Hu, H. Chen, C. Chen and Q. Liu, New J. Chem., 2007, 31, 1448.

29 R. Zaffaroni, T. B. Rauchfuss, D. L. Gray, L. De Goia and G. Zampelli, J. Am. Chem. Soc., 2012, 134, 19260.

30 M. L. Singleton, R. M. Jenkins, C. L. Klemashevich and M. Y. Darensbourg, C. R. Chem., 2008, 11, 861.

31 B. E. Barton, M. T. Olsen and T. B. Rauchfuss, J. Am. Chem. Soc., 2008, 130, 16834.

32 H. X. Li and T. B. Rauchfuss, J. Am. Chem. Soc., 2002, 124, 726.

33 b) L.-C. Song, Z.-Y. Yang, H.-Z. Bian, Y. Liu, H.-T. Wang, X.-F. Liu and Q.-M. Hu, Organometallics, 2005, 24, 6126.

34 L.-C. Song, Z.-Y. Yang, Y.-J. Hua, H.-T. Wang, Y. Liu and Q.-M. Hu, Organometallics, 2007, 26, 2106.

35 J. Windhager, M. Rudolph, S. Brautigam, H. Görls and W. Weigand, Eur. J. Inorg. Chem., 2007, 2748.

36 L.-C. Song, A.-G. Zhu and Y.-Q. Guo, Dalton Trans., 2016, 45, 5021.

37 L. R. Almazahreh, U.-P. Apfel, W. Imhof, M. Rudolph, H. Görls, J. Talarmin, P. Schollhammer, M. El-khateeb and W. Weigand, Organometallics, 2013, 32, 4523.

38 H. Abul-Futouh, L. R. Almazahreh, T. Sakamoto, N. Y. T. Stessman, D. L. Lichtenberger, R. S. Glass, H. Görls, M. El-khateeb, P. Schollhammer, G. Mloston and W. Weigand, Chem.-Eur. J., 2017, 23, 346.

39 H. Abul-Futouh, M. El-khateeb, H. Görls, K. J. Asali and W. Weigand, Dalton Trans., 2017, 4, 2937.

40 L. Duan, M. Wang, P. Li, Y. Na, N. Wang and L. Sun, Dalton Trans., 2007, 1277.

41 L.-C. Song, Z.-Y. Yang, H.-Z. Bian, Y. Liu, H.-T. Wang, X.-F. Liu and Q.-M. Hu, Organometallics, 2005, 24, 6126.

42 (a) C. M. Thomas, O. Rudiger, T. Liu, C. E. Carson, M. B. Hall and M. Y. Darensbourg, Organometallics, 2007, 26, 3976; (b) L. R. Almazahreh, W. Imhof, J. Talarmin, P. 
Schollhammer, H. Görls, M. El-khateeb and W. Weigand, Dalton Trans., 2015, 44, 7177;

(c) J. Windhager, U.-P. Apfel, T. Yoshino, N. Nakata, H. Görls, M. Rudolph, A. Ishii and W, Weigand, Chem. Asian J., 2010, 5, 1600.

43 P. Li, M. Wang, C. He, X. Liu, K. Jin and L. Sun, Eur. J. Inorg. Chem., 2007, 3718.

44 W. Gao, J. Ekstrom, J. Liu, C. Chen, L. Eriksson, L. Weng, B. Åkermark and L. Sun, Inorg. Chem., 2007, 46, 1981.

45 A. Jablonskyte, J. A. Wright and C. J. Pickett, Eur. J. Inorg. Chem., 2011, 1033.

46 Y.-C. Liu, C.-H. Lee, G.-H. Lee and M.-H. Chiang, Eur. J. Inorg. Chem., 2011, 1155.

47 H. Abul-Futouh, H. Görls and W. Weigand, Z. Anorg. Allg. Chem., 2017, 643, 1615.

48 A. Q. Daraosheh, H. Abul-Futouh, H. Görls and W. Weigand, Inorg. Chim. Acta, 2020, $\mathbf{5 0 3}, 119377$.

49 F. Gloaguen, J. D. Lawrence, M. Schmidt, S. R. Wilson and T. B. Rauchfuss, J. Am. Chem. Soc., 2001, 123, 12518.

50 C. M. Thomas, T. Liu, M. B. Hall and M. Y. Darensbourg, Inorg. Chem., 2008, 47, 7009.

51 S. Pullen, S. Maji, M. Stein and S. Ott, Dalton Trans., 2019, 48, 5933.

52 Z. Wang, J. He, S. Lü, W.-D. Jiang, Y. Wu, J. Jiang, Y. Xie, C. Mu, A. Li, Y.-L. Li and Q.-L. Li, Appl. Organometal. Chem., 2019, 33, e5184.

53 M.-Y. Hu, P.-H. Zhao, J.-R. Li, X.-L. Gu, X.-B. Jing and X.-F. Liu, Appl. Organometal. Chem., 2020, 34, e5523.

54 H.-M. Lin, J.-R. Li, C. Mu, A. Li, X.-F. Liu, P.-H. Zhao, Y.-L. Li, Z.-Q. Jiang and H.-K. Wu, Appl. Organometal. Chem., 2019, 33, e5196.

55 S. Tschierlei, S. Ott and R. Lomoth, Energy Environ. Sci., 2011, 4, 2340.

56 N. Wang, M. Wang, L. Chen and L. Sun, Dalton Trans., 2013, 42, 12059.

57 K. Fauvel, R. Mathieu and R. Poilblanc, Inorg. Chem., 1976, 15, 976.

58 (a) A. Jablonskyte, J. A. Wright and C. J. Pickett, Dalton Trans., 2010, 39, 3026; (b) X. Zhao, I. P. Georgakaki, M. L. Miller, R. Mejia-Rodriguez, C.-Y. Chiang and M. Y. Darensbourg, Inorg. Chem., 2002, 41, 3917; (c) X. Zhao, Y.-M. Hsiao, C.-H. Lai, J. H. Reibenspies and M. Y. darensbourg, Inorg. Chem., 2002, 41, 699; (d) S. Ghosh, A. Rahaman, G. Orton, G. Gregori, M. Bernat, U. Kulsume, N. Hollingsworth, K. B. Holt, S. E. Kabir and G. Hogarth, Eur. J. Inorg. Chem., 2019, 14, 4506. 
59 W. Lin Su, P. H. Huang, W.-T. Chen, W.-Y. Hsu, H.-Y. Chang, S.-Y. Ho, S.-P. Wanga and S.-G. Shyu, J. Chin. Chem. Soc., 2011, 58, 163.

60 R. H. Morris, Chem. Rev., 2016, 116, 8588.

61 A. B. P. Lever, Inorg. Chem., 1990, 29, 1271.

62 L. Schwartz, P. S. Singh, L. Eriksson, R. Lomoth and S. Ott, C. R. Chim., 2008, 11, 875.

63 J. Chen, A. K. Vannucci, C. A. Mebi, N. Okumura, S. C. Borowski, M. Swenson, L. T. Lockett, D. H. Evans, R. S. Glass and D. L. Lichtenberger, Organometallics, 2010, 29, 5330.

64 S. P. Best, S. J. Borg, J. M. White, M. Razavet and C. J. Pickett, Chem. Commun., 2007, 4348.

65 F. Gloaguen and T. B. Rauchfuss, Chem. Soc. Rev., 2009, 38, 100.

66 H. Abul-Futouh, M. El-khateeb, H. Görls and W. Weigand, Heteroat. Chem., 2018, 29, e21446.

67 G. Qian, W. Zhong, Z. Wei, H. Wang, Z. Xiao, L. Long and X. Liu, New J. Chem., 2015, 39, 9752.

68 R. S. Nicholson and I. Shain, Anal. Chem., 1965, 37, 178.

69 M. K. Harb, H. Alshurafa, M. El-khateeb, A. Al-Zuheiri, H. Görls, H. Abul-Futouh and W. Weigand, ChemistrySelect, 2018, 3, 8867.

70 R. Trautwein, H. Abul-Futouh, H. Görls, W. Imhof, L. R. Almazahreh and W. Weigand, New J. Chem., 2019, 43, 12580.

71 COLLECT, Data Collection Software, Nonius B.V., Netherlands, 1998.

72 Z. Otwinowski and W. Minor, Processing of X-Ray Diffraction Data Collected in Oscillation Mode, in Macromolecular Crystallography, Part A, ed. C. W. Carter and R. M. Sweet, Methods in Enzymology, Academic Press, San Diego, USA, 1997, vol. 276, p. 307.

73 L. Krause, R. Herbst-Irmer, G. M. Sheldrick and D. Stalke, J. Appl. Crystallogr., 2015, 48, 3.

74 G. M. Sheldrick, Acta Crystallogr., Sect. A: Found. Crystallogr., 2008, 64, 112.

75 G. M. Sheldrick, Acta Cryst., 2015, C71, 3.

76 C. F. Macrae, P. R. Edgington, P. McCabe, E. Pidcock, G. P. Shields, R. Taylor, M. Towler and J. van de Streek, J. Appl. Crystallogr., 2006, 39, 453. 